N. G. Vyhovska, orcid.org/0000-0001-7129-6169, A.Y.Polchanov, orcid.org/0000-0001-6019-9275,

T.P. Ostapchuk, orcid.org/0000-0001-9623-0481, V.V. Dovgaliuk, orcid.org/0000-0003-2732-8818
Zhytomyr Polytechnic State University, Zhytomyr, Ukraine, e-mail: polchanov@gmail.com

\title{
THE IMPACT OF SOLVENCY AND BUSINESS ACTIVITY ON PROFITABILITY OF MINING COMPANIES IN UKRAINE
}

Purpose. To identify the relationship between the profitability of mining companies and their solvency as well as business activity for making sound management decisions based on the formation of a formalized forecasting model, taking into account the scale and type of economic activity.

Methodology. The empirical basis of the study was formed based on key financial statements of 75 mining companies in Ukraine in 2014-2018 presented by the Youcontrol system. To achieve this goal, using the tool of correlation-regression analysis, a linear regression model was developed. It describes the dependence of the profitability of the assets on the equity ratio (share of equity in the total volume of sources of financing), asset turnover (ratio of revenue to average annual assets) based on the principal activity according to the Classifier of Economic Activity) and the scale of the business (based on annual revenue).

Findings. The proposed formalized forecasting model makes it possible to identify and evaluate the relationship between the profitability of mining companies and their solvency and business activity, taking into account the influence of the economies of scale and the characteristics of economic activity. Using the proposed model allows us to draw the following conclusions on planning directions for attracting internal or external sources of financing by companies:

- firstly, focusing on internal sources of financing of companies will have a greater effect compared to the use of credit resources (given the overload of companies in the extractive industry with debts, when developing a financial strategy, the priority should be the restructuring of obligations, the conversion of debt into the property, securitization);

- secondly, taking into account the influence of the factor of economies of scale in the mining industry determines the priority of state policy to support small businesses and create conditions for increasing the concentration of capital;

- thirdly, given the city-forming nature of companies in this industry, it is justified to maintain existing and launch new programs of financial support for companies, taking into account social consequences of the possible bankruptcy of such companies.

Formalization of the proposed areas allows mining companies to choose their future financial development strategy.

Originality. A formalized forecasting model is formed that allows identifying and evaluating the relationship between the profitability of mining companies and their solvency, as well as business activity, taking into account the influence of scale factors and characteristics of economic activity. Using the proposed model will contribute to the adoption of effective decisions on planning directions for attracting internal or external sources of financing by companies, choosing a future strategy for their development based on state financial support programs, introducing innovative forms of financing (securitization) or attracting foreign investment.

Practical value. It is possible to predict the profitability of the assets of the mining companies depending on the possible changes in their financial condition and business activity due to the inflow of foreign investments, taking into account the scale and type of economic activity, as well as to maximize the use of the existing financial potential of the company and justify the priorities of state support.

Keywords: extractive industry, random effects model, business activity, solvency, asset return

Introduction. Extractive industries play an important role in the national economy, as evidenced by their significant share in gross domestic product, the number of employees and ability to generate foreign exchange earnings. According to statistics, in 2018 the pre-tax financial result from the activities of large and medium-sized enterprises of the extractive industry amounted to UAH 105.8 billion, and the share of enterprises in the industry that made a profit is $64.0 \%$ of the total number of enterprises. For comparison: in 2016, the financial result amounted to UAH 23.5 billion (respectively, the share of profitable enterprises in the extractive industry was $58.5 \%$ of the total number of enterprises).

In Ukraine, approximately $35 \%$ of the area is the territory where labor-intensive mining operations have been carried out for more than 200 years. This includes the territories of the Central, Western Donbas, Lviv-Volyn coal basin, and others.

According to the results of 2018, among the 100 largest taxpayers in Ukraine there were 22 mining companies, including "UKRGAZVYDOBYVANNYA" JSC (paid UAH 41255.8 million), "NAFTOGAS OF UKRAINE" NJSC (UAH

(C) Vyhovska N. G., Polchanov A. Y., Ostapchuk T. P., Dovgaliuk V. V., 2020
28115.5 million), "UKRNAFTA" PJSC (UAH 15544.5 million). In general, the amount of revenues to the State Budget of Ukraine from extractive industries amounted to UAH 81.5 billion, which is $10.60 \%$ of all tax revenues.

According to the National Bank of Ukraine, in the first quarter of 2019, the extractive industry was one of the leaders in attracting foreign direct investment. Foreign investors can help to improve the capital structure of enterprises, in particular by increasing equity, the transformation of debt into a share in the authorized capital. In addition, it is possible to improve the position of enterprises in existing markets and enter new ones. When conducting a financial analysis of the state of the mining industry, it is necessary to take into account the presence of specific features of their operation. The main ones are:

1) the decisive influence of environmental factors on the enterprises of the industry;

2) location of enterprises near the mineral deposit;

3) the maximum service life of the mine, which is determined by the volume of mineral reserves;

4) a significant level of capital intensity of such enterprises, due to the need for constant financial support for treatment works;

5) complexity and increased danger of mining operations; 
6) lower level of comfort of working conditions at the enterprises of the mining industry, than in other branches of the industry;

7) features of the stages of the life cycle, which are characterized by specific types of work and technological features;

8) depletion of natural resources, which in the future leads to the liquidation of mines, which, in turn, leads to mass layoffs, their migration and the need to generate a significant amount of funds for compensation;

9) city-forming nature of mining enterprises.

The relevance of mining research is growing in the context of the approved Declaration and Sustainable Development Action Plan, which were signed by 172 countries in Rio de Janeiro in 2012. According to the results of the UN Conferences on Environment and Development, it is necessary to ensure the balance of the economic, social and ecological system in the management and maximum satisfaction of the interests of producers in obtaining maximum profits.

Given this, it is important to study the quantitative impact of indicators of financial condition (liquidity and autonomy ratios), business activity, scale and business specifics on the efficiency of extractive industries in modern economic conditions. Addressing this issue will facilitate the adoption of prudent and effective management decisions aimed at increasing the profitability of mining companies and the effective use of their financial potential.

Literature review. The use of methods of economic and mathematical modeling in order to identify the impact of individual indicators on the efficiency (effectiveness, profitability) of economic entities can be traced in the works:

1. "The impact of ownership and other corporate characteristics on performance of V4 companies" [1] in terms of the impact of capital structure and a number of corporate characteristics on the return on assets of enterprises from Central and Eastern Europe.

2. "Capital structure and firm performance of non-financial listed companies: Cross-sector empirical evidences from Vietnam" [2] concerning the impact of the ratio of short-term and long-term liabilities to assets of non-financial companies in Vietnam on their profitability.

3. "Capital structure and firm performance: evidence of Germany under IFRS adoption" [3] in terms of the impact of borrowed capital on the efficiency of non-financial companies in Germany, whose shares are listed on the stock exchange.

4. "The Investigation of Relationship between Structure of Assets and the Performance of Firms Evidence from Tehran Stock Exchange" [4] concerning the impact of asset structure on the performance of Iranian companies traded on national stock exchanges, and a similar study "The impact of capital structure on financial performance in Romanian listed companies" [5] by the example of Romanian enterprises.

5. "The impact of capital structure on the performance of construction companies: A study from Vietnam stock exchanges" [6] on identifying the impact of asset and capital structure on the profitability of construction companies.

6. "Impact of capital structure on firm's performance: Focusing on non-financial listed Egyptian firms" [7] concerning the dependence of the efficiency of non-financial companies in Egypt on the share of short-term and long-term liabilities in the total amount of funding.

In this case, indicators of return on assets, return on equity, as well as earnings per share were used as dependent variables.

The issue of improving the efficiency of mining enterprises was considered in a number of foreign publications, among which we can note the works:

1. "Environmental performance and financial report integrity: challenges for the mining sector in Indonesia" [8] on the impact of a number of environmental performance indicators on the financial condition of mining enterprises.

2. "Evaluating intellectual capital and its impact on financial performance: empirical evidence from Indian electricity, mining and asset financing service sectors" [9] concerning the impact of intellectual capital structure indicators on changes in profitability, productivity and value of companies in mining and related industries.

3. "An empirical study of hybrid DEA and grey system theory on analyzing performance: a case from Indian mining industry" $[10]$ in terms of forecasting the results of enterprises based on the analysis of time series.

4. "A license to operate? An empirical examination of the influence of environmental and social performance on the financial performance of mining sector firms" [11] regarding the study on the relationship between criteria and indicators for assessing corporate, environmental and social responsibility with the financial efficiency of the largest mining companies.

The issues of formation and development of the mining and metallurgical industry of Ukraine are reflected in the following scientific works:

1. "Innovative challenges and post-crisis prospects of Ukrainian mining and metallurgical industry" [12] in the context of improving the model of macroeconomic mechanism of state investment expansion and the formation of sound recommendations to stimulate growth of innovation and investment expenditures of enterprises in mining and metallurgical complex.

2. "The strategy of sustainable innovative society-oriented development of Ukrainian economy (by the example of mineral resource industry)" [13] on the formation and implementation of a strategy of sustainable innovative socially oriented economic development in the context of solving energy security issues of Ukraine.

3. "Simulation analysis of relationship between production cost and natural environment of iron ore extraction and processing" [14] in the context of the influence of natural factors on the dynamics of costs associated with iron ore extraction, its grinding, beneficiation and agglomeration.

4. "Accounting and analytical problems at coal-mining enterprises of Ukraine in terms of European integration" [15] the development of accounting for and analytical support of mining enterprises.

In addition, foreign research was conducted, as a rule, on the example of companies whose shares were traded on stock exchanges, which is not typical for domestic realities. Regarding the issue of ensuring the efficiency of the extractive industries of Ukraine, we found insufficient attention to assessing the quantitative impact of financial condition, business activity and other corporate characteristics on the profitability of companies.

Unsolved aspects of the problem. Evaluation of scientific achievements of domestic and foreign scientists shows that the issue of the impact of solvency and business activity on the efficiency of mining companies has remained insufficiently covered. In the current economic and political instability, the study of the formation and implementation of financial strategy, which would be based on the relationship of indicators of solvency and business activity, scale and main economic activity with profitability, would make the most effective use of available financial potential to achieve set strategic goals.

Purpose. The aim of the article is to identify the relationship between the profitability of extractive industries with their solvency and business activity to make sound management decisions based on the formation of a formalized forecast model, taking into account the scale and type of economic activity.

Methods. The financial statements of 75 enterprises, the main economic activity of which is the extraction of coal and lignite, crude oil and natural gas, metal ores in accordance with the Classifier of Economic Activities (NACE) for 20142018 presented by Youcontrol system data were the empirical basis of the study. At the same time, the sample included enterprises in the industry that were not in the process of termination. The sample was formed in such a way as to evenly represent enterprises from different sectors (mining of coal and lignite, extraction of crude oil and natural gas, extraction of metal ores), in particular 25 from each sector. 
Indicators of return on assets, return on current assets, net margin (ratio of net profit or loss to revenue) and operating profitability of assets (ratio of operating profit to assets) were used to assess profitability; current and absolute liquidity ratios, as well as the equity ratio were used to assess solvency; and an indicator of asset turnover, working capital turnover (the ratio of net profit or loss to the difference between current assets and current liabilities), as well as the turnover of receivables were used to assess business activity.

The scale of business was determined separately, based on the amount of annual income (according to the Economic Code of Ukraine). Thus, small enterprises were defined as enterprises with an annual income of less than 10 million euros, large ones are enterprises with an annual income of more than 50 million euros, and the rest are medium-sized. At the same time, the annual income was determined taking into account the average rate for the period of the official exchange rate of hryvnia to the euro in the corresponding year (in $2014-1571.59 \mathrm{UAH}$, in 2015 - 2422.87 UAH, in 2016 - $2829.19 \mathrm{UAH}$, in 2017 $3000.42 \mathrm{UAH}$ and in 2018 - $3214.29 \mathrm{UAH}$ per 100 euros).

In addition, depending on the main type of economic activity, enterprises were divided into three groups: enterprises for the extraction of coal and lignite (Chapter 05 of the NACE), enterprises for the extraction of crude oil and natural gas (Chapter 06 of the NACE) and enterprises for the extraction of metal ores (Chapter 07 of the NACE).

Results. According to the Youcontrol system, the total revenue of enterprises in 2018 amounted to $88.84 \%$ of the total revenue of enterprises whose main activity according to the NACE belongs to Section B "Mining and Quarrying", which gives grounds to claim that the industry leaders who identify areas for its strategic development were selected for the study. The total revenues of enterprises for the extraction of coal and lignite, enterprises for the extraction of crude oil and natural gas and enterprises for the extraction of metal ores were 14.15, 39.19 and $35.14 \%$ of the total revenue of the mining industry, respectively.

The results of the statistical analysis of the solvency and liquidity indicators of the sample enterprises (Table 1) made it possible to draw the following conclusions:

1) most enterprises experienced a liquidity deficit, as the median value of the current liquidity ratio did not exceed 1.0 (except in 2017), and the median value of the absolute liquidity ratio did not exceed 0.2 . Given that this trend continued during 2014-2018, it can be assumed that the problems of debt repayment persist;

2) the financing of the activities of most enterprises was carried out at the expense of borrowed capital, as evidenced by the median values of the equity ratio which did not exceed 0.5 . It should be noted that the values of the equity ratio for metal ore mining enterprises are higher by 0.41 on average, as well as the existence of enterprises with signs of actual insolvency (negative value of equity).

According to the results of the analysis of business activity indicators of the selected enterprises (Table 2) the following tendencies were revealed:

1) increase in the productivity of the use of assets, as evidenced by the growth of the turnover of assets each year by an average of 0.07 . At the same time, crude oil and natural gas production enterprises, compared to other enterprises, had higher assets turnover (on average by 0.58 );

2) the efficiency of the use of working capital was lower than the market average indicators in 2014-2016, but increased in 2017-2018;

3) for most companies, the ability to collect receivables from customers corresponded to the general situation in the industry, as evidenced by the median values of the turnover of receivables. At the same time, this indicator was higher for crude oil and natural gas extraction enterprises (on average by 1.58 ) and lower for metal ore extraction enterprises (on average by 1.41) compared to coal and lignite mining enterprises.
Table 1

Indicators of solvency and liquidity of the largest companies of the mining industry in 2014-2018

\begin{tabular}{|l|l|c|c|c|c|c|}
\hline \multicolumn{2}{|c|}{ Indicator } & 2014 & 2015 & 2016 & 2017 & 2018 \\
\hline \multirow{4}{*}{$\begin{array}{l}\text { Current } \\
\text { Ratio }\end{array}$} & Min & 0.02 & 0.08 & 0.03 & 0.04 & 0.03 \\
\cline { 2 - 7 } & Median & 0.88 & 0.85 & 0.85 & 1.09 & 0.98 \\
\cline { 2 - 7 } & Max & 158.33 & 11.23 & 13.66 & 14.31 & 20.13 \\
\cline { 2 - 7 } & Mean & 4.23 & 1.58 & 1.88 & 1.82 & 1.66 \\
\cline { 2 - 7 } & SD & 19.53 & 2.16 & 2.88 & 2.61 & 2.74 \\
\hline \multirow{4}{*}{$\begin{array}{l}\text { Cash } \\
\text { Ratio }\end{array}$} & Min & 0.00 & 0.00 & 0.00 & 0.00 & 0.00 \\
\cline { 2 - 7 } & Median & 0.01 & 0.01 & 0.01 & 0.01 & 0.01 \\
\cline { 2 - 7 } & Max & 116.33 & 5.00 & 2.17 & 2.29 & 3.59 \\
\cline { 2 - 7 } & Mean & 1.99 & 0.17 & 0.11 & 0.14 & 0.12 \\
\cline { 2 - 7 } & SD & 14.42 & 0.64 & 0.33 & 0.35 & 0.45 \\
\hline \multirow{4}{*}{$\begin{array}{l}\text { Equity } \\
\text { Ratio }\end{array}$} & Min & -1.88 & -3.73 & -12.50 & -16.68 & -6.89 \\
\cline { 2 - 7 } & Median & 0.33 & 0.23 & 0.25 & 0.29 & 0.34 \\
\cline { 2 - 7 } & Max & 0.99 & 0.94 & 1.00 & 0.94 & 0.95 \\
\cline { 2 - 7 } & Mean & 0.19 & 0.08 & -0.11 & -0.17 & -0.02 \\
\cline { 2 - 7 } & SD & 0.62 & 0.80 & 1.74 & 2.20 & 1.38 \\
\hline
\end{tabular}

Note: Min - minimum value, Median - median value, Max maximum value, Mean - average value, SD - standard deviation

Source: own calculations based on data of 75 companies

Table 2

Indicators of business activity of the largest companies of the mining industry in 2014-2018

\begin{tabular}{|l|l|c|c|c|c|c|}
\hline \multicolumn{2}{|c|}{ Indicator } & 2014 & 2015 & 2016 & 2017 & 2018 \\
\hline \multirow{4}{*}{$\begin{array}{l}\text { Total } \\
\text { Assets } \\
\text { Turnover }\end{array}$} & Min & 0.00 & 0.00 & 0.00 & 0.00 & 0.00 \\
\cline { 2 - 7 } & Median & 0.50 & 0.60 & 0.60 & 0.70 & 0.80 \\
\cline { 2 - 7 } & Max & 3.00 & 7.90 & 10.10 & 4.40 & 3.80 \\
\cline { 2 - 7 } & Mean & 0.66 & 0.88 & 0.93 & 0.96 & 1.01 \\
\cline { 2 - 7 } & SD & 0.62 & 1.22 & 1.55 & 0.93 & 0.77 \\
\hline \multirow{4}{*}{$\begin{array}{l}\text { Working } \\
\text { Capital }\end{array}$} & Min & -31.30 & -29.20 & -538.10 & -110.40 & -135.10 \\
\cline { 2 - 7 } & Median & 0.00 & -0.15 & -0.20 & 0.30 & 1.50 \\
\cline { 2 - 7 } & Max & 207.80 & 470.80 & 462.90 & 770.40 & 385.40 \\
\cline { 2 - 7 } & Mean & 3.88 & 8.38 & -1.45 & 12.08 & 5.77 \\
\cline { 2 - 7 } & SD & 28.92 & 59.17 & 85.38 & 92.36 & 49.03 \\
\hline \multirow{4}{*}{$\begin{array}{l}\text { Receivables } \\
\text { Turnover }\end{array}$} & Min & 0.00 & 0.00 & 0.00 & 0.00 & 0.00 \\
\cline { 2 - 7 } & Median & 2.50 & 2.30 & 2.05 & 2.45 & 2.90 \\
\cline { 2 - 7 } & Max & 33.60 & 51.70 & 17.00 & 36.50 & 27.80 \\
\cline { 2 - 7 } & Mean & 4.24 & 5.33 & 3.43 & 4.26 & 4.08 \\
\cline { 2 - 7 } & SD & 5.47 & 8.56 & 4.04 & 5.95 & 4.75 \\
\hline
\end{tabular}

Note: Min - minimum value, Median - median value, Max maximum value, Mean - average value, SD - standard deviation

Source: own calculations based on data of 75 companies

Based on the assessment of key indicators of profitability of the largest enterprises of the extractive industry (Table 3), the following changes were identified:

1) a gradual increase in the efficiency of the assets use of the sampled enterprises (profitability increased by an average of 0.05 annually), with the highest values of this indicator being in the enterprises of crude oil and natural gas. At the same time, most enterprises remained profitable during 2014-2018, as evidenced by the median value of the return on assets. The 
Indicators of profitability of the largest companies of the mining industry in 2014-2018

\begin{tabular}{|c|c|c|c|c|c|c|}
\hline \multicolumn{2}{|c|}{ Indicator } & 2014 & 2015 & 2016 & 2017 & 2018 \\
\hline \multirow[t]{5}{*}{ Return on Assets } & Min & -1.48 & -2.05 & -5.71 & -0.82 & -0.83 \\
\hline & Median & 0.01 & 0.00 & 0.01 & 0.05 & 0.07 \\
\hline & Max & 0.49 & 0.39 & 0.55 & 0.93 & 0.77 \\
\hline & Mean & -0.07 & -0.13 & -0.09 & 0.07 & 0.09 \\
\hline & SD & 0.33 & 0.43 & 0.73 & 0.28 & 0.25 \\
\hline \multirow{5}{*}{$\begin{array}{l}\text { Return on current } \\
\text { assets }\end{array}$} & Min & -4.21 & -10.53 & -6.02 & -4.24 & -3.78 \\
\hline & Median & 0.05 & 0.00 & 0.01 & 0.07 & 0.12 \\
\hline & Max & 2.69 & 1.07 & 4.67 & 4.26 & 4.78 \\
\hline & Mean & -0.32 & -0.57 & -0.15 & 0.15 & 0.22 \\
\hline & SD & 1.19 & 1.85 & 1.31 & 0.92 & 0.88 \\
\hline \multirow[t]{5}{*}{ Net Profit Margin } & Min & -360.54 & -901.80 & -3372.98 & -228.37 & -6.76 \\
\hline & Median & 0.02 & 0.00 & 0.02 & 0.06 & 0.08 \\
\hline & Max & 0.69 & 0.38 & 0.59 & 0.63 & 0.59 \\
\hline & Mean & -9.07 & -17.14 & -50.32 & -3.54 & -0.09 \\
\hline & $\mathrm{SD}$ & 49.44 & 112.13 & 406.00 & 27.19 & 0.97 \\
\hline \multirow{5}{*}{$\begin{array}{l}\text { Return on Total } \\
\text { Assets }\end{array}$} & Min & -1.37 & -2.05 & -5.71 & -0.77 & -0.74 \\
\hline & Median & 0.05 & 0.02 & 0.02 & 0.05 & 0.10 \\
\hline & Max & 0.61 & 0.47 & 0.68 & 1.18 & 0.97 \\
\hline & Mean & -0.03 & -0.09 & -0.06 & 0.11 & 0.14 \\
\hline & SD & 0.34 & 0.43 & 0.73 & 0.31 & 0.29 \\
\hline
\end{tabular}

Note: Min - minimum value, Median - median value, Max - maximum value, Mean - average value, SD - standard deviation

Source: own calculations based on data of 75 companies

situation was similar with the return on current assets and operating return on assets (annual growth in return on current assets and relatively higher values for crude oil and natural gas production companies);

2) the ratio of net financial result and revenue as a whole exceeded the industry average values, without significant differences for economic activities.

Thus, during 2014-2018, most of the surveyed enterprises experienced financial problems, but intensified their activities (which is confirmed by the values of asset and receivables turnover). This, in turn, provided an opportunity to increase the profitability of enterprises (as evidenced by the growing level of return on assets). In addition, depending on the main type of activity, there was a difference in the financial condition and profitability of enterprises.

In order to develop an econometric model that would describe the relationship between the profitability of extractive industries with their solvency and business activity, it is necessary to study the closeness of the relationship between the main financial ratios (Table 4). The results of the correlation analysis give grounds to assert the existence of a statically significant linear interdependence (at the level of $5 \%$ ) of certain indicators of profitability with certain indicators of solvency and business activity, in particular:

- between return on assets and autonomy ratios $(R=$ $=0.6221)$, assets turnover $(R=0.2818)$;

- between the return on current assets and autonomy ratios $(R=0.444)$, assets turnover $(R=0.2544)$;

- between the net margin and the autonomy ratios $(R=$ $=0.1931)$;

- between operating return on assets and autonomy ratios $(R=0.6065)$, assets turnover $(0.2892)$.

In addition, a close relationship is expected between return on assets and operating profitability, between current and absolute liquidity ratios, and between asset turnover, working capital turnover and receivables turnover.

A linear regression model was used to confirm the assumption that there was a relationship between the profitability of extractive industries and their solvency and business activity, taking into account the scale and type of economic activity. The return on assets ( $R O A)$ was determined as a dependent value for the construction of the econometric model, which, unlike other profitability indicators, provides an opportunity to more fully assess the efficiency of resources invested in the enterprise and is more often used to characterize profitability.

The equity ratio (Equity to Assets) and the ratio of asset turnover (Assets_Turnover) were used as the factors, i.e. as the main indicators of solvency and business activity, which have the closest relationship with the dependent variable. However, there is no statistically significant linear relationship between the autonomy ratios and assets turnover ratios, which makes it possible to assert the absence of multicollinearity. In addition, the scale of business, which is determined by the amount of revenue (Size) and the type of economic activity in accordance with the NACE (Business) were among the factors.

Based on this, the econometric model looks as follows

$$
\begin{gathered}
\text { ROA= } \beta_{0}+\beta_{1} * \text { Equity_to_Assets }+\beta_{2} * \text { Assets_Turnover }+ \\
+\beta_{3} * \text { Size }+\beta_{4} * \text { Business }+\varepsilon .
\end{gathered}
$$

To achieve this goal, the following hypotheses were set out:

Hypothesis $1\left(H_{1}\right)$. The change in the share of equity in the total amount of financial resources affects the change in the return on assets of extractive industries $\left(H_{1}: \beta_{1} \neq 0\right)$. It is expected that in the conditions of growth of the cost of borrowed resources there is a statistically significant direct linear relationship between profitability and autonomy ratios.

Hypothesis 2. $\left(\mathrm{H}_{2}\right)$. The change in asset turnover affects the change in the return on assets of extractive industries $\left(H_{2}: \beta_{2} \neq 0\right)$. Based on the rate of capital turnover, there will be a statistically significant direct linear relationship between return on assets and asset turnover.

Hypothesis 3. $\left(H_{3}\right)$. The scale of business affects the change in the return on assets of extractive industries $\left(H_{3}: \beta_{3} \neq 0\right)$. Due to the effect of scale, large businesses are expected to have higher return on assets than small businesses. 
Correlation matrix of profitability, solvency and business activity indicators

\begin{tabular}{|c|c|c|c|c|c|c|c|c|c|c|}
\hline & $\begin{array}{l}\text { Return } \\
\text { on Assets }\end{array}$ & $\begin{array}{c}\text { Return on } \\
\text { Current } \\
\text { Assets }\end{array}$ & $\begin{array}{c}\text { Net } \\
\text { Profit } \\
\text { Margin }\end{array}$ & $\begin{array}{l}\text { Return } \\
\text { on Total } \\
\text { Assets }\end{array}$ & $\begin{array}{c}\text { Current } \\
\text { Ratio }\end{array}$ & $\begin{array}{l}\text { Cash } \\
\text { Ratio }\end{array}$ & $\begin{array}{l}\text { Equity- } \\
\text { to-Assets }\end{array}$ & $\begin{array}{c}\text { Total } \\
\text { Assets } \\
\text { Turnover }\end{array}$ & $\begin{array}{c}\text { Total } \\
\text { Assets } \\
\text { Turnover }\end{array}$ & $\begin{array}{l}\text { Working } \\
\text { Capital } \\
\text { Turnover }\end{array}$ \\
\hline Return on Assets & 1 & & & & & & & & & \\
\hline $\begin{array}{l}\text { Return on Current } \\
\text { Assets }\end{array}$ & $0.7034^{*}$ & 1 & & & & & & & & \\
\hline Net Profit Margin & $0.2188^{*}$ & $0.1225^{*}$ & 1 & & & & & & & \\
\hline Return on Total Assets & $0.9933^{*}$ & $0.6935^{*}$ & $0.2086^{*}$ & 1 & & & & & & \\
\hline Current Ratio & 0.0025 & 0.0252 & 0.0452 & 0.0008 & 1 & & & & & \\
\hline Cash Ratio & -0.049 & -0.0097 & 0.0117 & -0.0515 & $0.9617^{*}$ & 1 & & & & \\
\hline Equity-to-Assets & $0.6221^{*}$ & $0.444^{*}$ & $0.1931^{*}$ & $0.6065^{*}$ & 0.0982 & 0.0443 & 1 & & & \\
\hline Total Assets Turnover & $0.2818^{*}$ & $0.2544^{*}$ & 0.0713 & $0.2892^{*}$ & -0.0563 & -0.0484 & 0.0936 & 1 & & \\
\hline Total Assets Turnover & 0.0169 & 0.0138 & 0.0073 & 0.0208 & -0.0072 & -0.0049 & -0.0669 & $0.2654^{*}$ & 1 & \\
\hline $\begin{array}{l}\text { Working Capital } \\
\text { Turnover }\end{array}$ & 0.0828 & 0.0573 & 0.06 & 0.088 & -0.0898 & -0.0358 & 0.0332 & $0.3119^{*}$ & 0.0077 & 1 \\
\hline
\end{tabular}

Note: ${ }^{*}-5 \%$ significance levels

Hypothesis 4. $\left(\mathrm{H}_{4}\right)$. The type of economic activity affects the change in the return on assets of extractive industries $\left(H_{4}: \beta_{4} \neq 0\right)$. It is assumed that the existence of technological features of economic activity affects profitability.

Taking into consideration the existence of heteroscedasticity, found while construction of the model by the usual method of least squares, we used the weighted method of least squares.

The results of the regression analysis (Table 5) provide an opportunity to draw conclusions about the significance of the model parameters and its adequacy. In particular, the adjusted values of the coefficient of determination (Adjusted $R^{2}=0.585453$ ), indicate that the change in return on assets by $59 \%$ is determined by the change of factors taken into account in the model.

Hypothesis 1 was confirmed, according to which the growth of the share of equity in the assets of enterprises by 1 percentage point causes an increase in return on assets by an average of 0.18 percentage points, as other things being equal, as well as Hypothesis 2, according to which the growth of the assets turnover ratio of enterprises by 1 percentage point causes an increase in return on assets by an average of 0.07 percentage points, as other things being equal.

In addition, Hypothesis 3 was confirmed: the profitability of small enterprises was lower by 0.07 percentage points on average than the profitability of large and medium enterprises. The difference in profitability of large and medium-sized enterprises is not statistically significant. Along with this, the profitability of enterprises engaged in the extraction of crude oil and natural gas (compared to other enterprises in the extractive industry) by an average of 0.09 percentage points is higher (Hypothesis 4). At the same time, the difference in profitability of lignite and coal mining enterprises with metal ore mining enterprises is statistically insignificant.

Conclusions. The proposed formalized forecasting model allows identifying and evaluating the relationship between the profitability of extractive industries and their solvency and business activity, taking into account the influence of the factor of scale and the peculiarities of economic activity.

Table 5

Regression analysis

\begin{tabular}{|c|c|c|c|c|c|c|}
\hline & Coefficient & Std. Error & $z$ & p-value & & \\
\hline const & -0.0477313 & 0.0168142 & -2.839 & 0.0048 & & $* * *$ \\
\hline Equity_to_Assets & 0.178679 & 0.0111320 & 16.05 & $<0.0001$ & & $* * *$ \\
\hline Assets_Turnover & 0.0651937 & 0.00729073 & 8.942 & $<0.0001$ & & $* * *$ \\
\hline Size:Small & -0.0717332 & 0.0151174 & -4.745 & $<0.0001$ & & $* * *$ \\
\hline Size:Large & -0.0141734 & 0.0160652 & -0.8822 & 0.3783 & & \\
\hline Business:Petroleum & 0.0869048 & 0.0141134 & 6.158 & $<0.0001$ & & $* * *$ \\
\hline Business:Metal & 0.00719642 & 0.0127856 & 0.5629 & 0.5739 & & \\
\hline Sum squared resid & 316.2058 & \multicolumn{2}{|c|}{ S.E. of regression } & \multicolumn{3}{|c|}{0.955976} \\
\hline R-squared & 0.592519 & \multicolumn{2}{|c|}{ Adjusted R-squared } & \multicolumn{3}{|c|}{0.585453} \\
\hline $\mathrm{F}$ & 83.85329 & \multicolumn{2}{|c|}{ P-value(F) } & \multicolumn{3}{|c|}{$1.91 \mathrm{e}-64$} \\
\hline Log-likelihood & -481.4571 & \multicolumn{2}{|c|}{ Akaike criterion } & \multicolumn{3}{|c|}{976.9142} \\
\hline Schwarz criterion & 1003.979 & \multicolumn{2}{|c|}{ Hannan-Quinn } & \multicolumn{3}{|c|}{987.6837} \\
\hline
\end{tabular}

Notes:

1. The weighted least squares method is used

2. Basic version of the enterprise in the model: an enterprise with an annual income in the range of 10-50 million euros (medium business) with the main type of economic activity "Extraction of lignite and coal" 
This provided an opportunity to draw such conclusions.

First, the focus on domestic sources of financing of enterprises will have a greater effect compared to the use of credit resources. At the same time, compared to existing developments, it is possible to quantify the impact of increasing the share of equity on the return on assets of enterprises. In general, extractive industries are overburdened with debt, which has a negative impact on profitability. In such circumstances, the restructuring of liabilities and the conversion of debt into property should be an important step in business management. The use of such an innovative method of debt transformation as securitization looks quite promising.

In addition, the state as a regulator of market relations should promote the inflow of foreign investment.

Secondly, it is possible to accelerate the turnover of assets due to entering new markets and expanding existing ones, which will have a positive influence on the return on assets. Particular attention will need to be paid to the study on the consequences of the possible lifting of sanctions by the Russian Federation on Ukrainian enterprises, in particular, "UMCC" JSC and "POKROVSKIY Ore Mining \& Processing Intergrated Plant", JSC on the development of the domestic extractive industry.

Thirdly, the mining industry clearly shows the effect of scale, which is seen in the existence of a difference between the profitability of small and other enterprises. In such conditions, the priority of public policy should be to support small businesses and create conditions for increasing the concentration of capital, which, in turn, will increase the return on assets of enterprises.

Fourthly, there is a significant difference between the return on assets of enterprises engaged in the extraction of crude oil and natural gas with the return on assets of enterprises in related industries (coal and metal ores). In view of this, it is justified to maintain existing and launch new programs of financial support for enterprises, taking into account the social consequences of bankruptcy of such enterprises.

The practical value of the study is the ability to predict the profitability of assets of extractive industries, based on changes in financial indicators, which will allow companies to make sound management decisions at the microeconomic level (in developing and implementing corporate financial strategy) and at the macroeconomic level (in the part of substantiation of the main directions of state support of the extractive industry).

References.

1. Procházka, D. (2017). The Impact of Ownership and Other Corporate Characteristics on Performance of V4 Companies. Journal of International Studies, 10(2), 204-218. https://doi. org/10.14254/2071-8330.2017/10-2/15.

2. Nguyen, T., \& Nguyen, H. (2020). Capital structure and firm performance of non-financial listed companies: Crosssector empirical evidences from Vietnam. Accounting, 6(2), 137-150. https://doi.org/10.5267/j.ac.2019.11.002.

3. Abdullah, H., \& Tursoy, T. (2019). Capital structure and firm performance: evidence of Germany under IFRS adoption. Review of Managerial Science, 1-20. https://doi.org/10.1007/ s11846-019-00344-5.

4. Sattoriva, C., Kootanaee, A., Seyyedi, J., \& Ebrahimi, E. (2013). The Investigation of Relationship between Structure of Assets and the Performance of Firms Evidence from Tehran Stock Exchang. International Journal of Economics, Business and Finance, 1(8), 220-227.

5. Vătavu, S. (2015). The Impact of Capital Structure on Financial Performance in Romanian Listed Companies. Procedia Economics and Finance, 32, 1314-1322. https://doi. org/10.1016/S2212-5671(15)01508-7.

6. Vu, T., Le, T., \& Nguyen, T. (2020). The impact of capital structure on the performance of construction companies: A study from Vietnam stock exchanges. Accounting, 6(2), 169176. https://doi.org/10.5267/j.ac.2019.10.006.

7. Sakr, A., \& Bedeir, A. (2019). Impact of capital structure on firm's performance: Focusing on non-financial listed Egyp- tian firms. International Journal of Financial Research, 10(6), 78-87. https://doi.org/10.5430/ijfr.v10n6p78.

8. Mayangsari, S. (2018). Environmental Performance and Financial Report Integrity: Challenges for the Mining Sector in Indonesia. IOP Conference Series: Earth and Environmental Science, 106 (January): 012064. https://doi.org/10.1088/17551315/106/1/012064.

9. Narwal, K., \& Yadav, N. (2017). Evaluating Intellectual Capital and Its Impact on Financial Performance: Empirical Evidence from Indian Electricity, Mining and Asset Financing Service Sectors. International Journal of Learning and Intellectual Capital, 14(4), 319-337. https://doi.org/10.1504/IJLIC.2017.087376.

10. Wang, L., Tran, T., \& Nguyen, N. (2015). An Empirical Study of Hybrid DEA and Grey System Theory on Analyzing Performance: A Case from Indian Mining Industry. Journal of Applied Mathematics, 2015, 1-15. https://doi.org/10.1155/2015/395360. 11. Walsh, P. R. (2014). A License to Operate? An Empirical Examination of the Influence of Environmental and Social Performance on the Financial Performance of Mining Sector Firms. International Journal of Innovation and Sustainable Development, 8(2), 190-206. https://doi.org/10.1504/IJISD.2014.062851.

12. Bilotserkivets, V. V., \& Zavhorodnia, O. O. (2017). Innovative Challenges and Post-Crisis Prospects of Ukrainian Mining and Metallurgical Industry. Naukovyi Visnyk Natsionalnoho Hirnychoho Universytetu, (2), 149-156.

13. Bondar-Pidhurska, O. V., \& Solovyov, V.P. (2017). The Strategy of Sustainable Innovative Society-Oriented Development of Ukrainian Economy (by the Example of Mineral Resource Industry). Naukovyi Visnyk Natsionalnoho Hirnychoho Universytetu, (4), 122-132.

14. Voloshyna, S. V., \& Kostakova, L. D. (2017). Simulation Analysis of Relationship between Production Cost and Natural Environment of Iron Ore Extraction and Processing. Naukovyi Visnyk Natsionalnoho Hirnychoho Universytetu, (4), 112-121.

15. Petruk, O., \& Makurin, A. (2016). Accounting and analytical problems at coal-mining enterprises of Ukraine in terms of European integration. Economic Annals-XXI, (9-10), 95100. https://doi.org/10.21003/ea.V161-21.

\section{Вплив платоспроможності та ділової активності на прибутковість підприємств добувної галузі України}

\author{
Н. Г. Виговська, А. Ю. Полчанов, Т. П. Остапчук, \\ В. В. Довгалюк
}

Державний університет «Житомирська політехніка», м. Житомир, Україна, e-mail: polchanov@gmail.com

Мета. Виявлення взаємозв'язку прибутковості підприємств добувної галузі з їх платоспроможністю й діловою активністю для прийняття оптимальних управлінських рішень на основі формування формалізованої прогнозної моделі, з урахуванням масштабів і виду економічної діяльності.

Методика. Емпірична база дослідження була сформована на основі ключових показників фінансової звітності 75 підприємств добувної промисловості України у 20142018 pp. за допомогою системи Youcontrol. 3 метою досягнення поставленої мети за допомогою інструментарію кореляційно-регресійного аналізу побудована модель лінійної регресії, що описує залежність рентабельності активів від коефіцієнта автономії (частки власного капіталу в загальному обсязі джерел фінансування), оборотності активів (співвідношення виручки до середньорічних активів), виду економічної діяльності (виходячи з основного виду діяльності, відповідно до Класифікатора виду економічної діяльності) та масштабів бізнесу (виходячи з річного обсягу виручки).

Результати. Запропонована формалізована прогнозна модель дозволяє виявити та оцінити взаємозв'язок між 
прибутковістю підприємств добувної галузі та їх платоспроможністю й діловою активністю, з урахуванням впливу фактору ефекту масштабу та особливостей здійснення економічної діяльності. Використання запропонованої моделі дозволяє зробити такі висновки щодо планування напрямів залучення внутрішніх або зовнішніх джерел фінансування підприємствами:

- по-перше, орієнтація на внутрішні джерела фінансування діяльності підприємств матиме більший ефект порівняно з використанням кредитних ресурсів. Зважаючи на перевантаженість підприємств добувної галузі боргами, при розробці фінансової стратегії пріоритетним напрямом повинна стати реструктуризація зобов'язань, конвертація боргу у власність, сек’юритизація;

- по-друге, врахування впливу фактору ефекту масштабу в добувній промисловості визначає пріоритетом державної політики підтримку малого бізнесу та створення умов для підвищення концентрації капіталу;

- по-третє, враховуючи містоутворюючий характер підприємств цієї галузі, обгрунтованим є збереження існуючих і запуск нових програм фінансової підтримки підприємств, ураховуючи соціальні наслідки можливого банкрутства таких підприємств.

Формалізація запропонованих напрямів дозволяе підприємствам добувної галузі здійснити вибір майбутньої стратегії їх фінансового розвитку.

Наукова новизна. Полягає у формуванні формалізованої прогнозної моделі, що дозволяє виявити та оцінити взаємозв'язок між прибутковістю підприємств добувної галузі та їх платоспроможністю й діловою активністю, 3 урахуванням впливу фактору масштабу та особливостей здійснення економічної діяльності. Використання запропонованої моделі сприятиме прийняттю ефективних управлінських рішень щодо планування напрямів залучення внутрішніх або зовнішніх джерел фінансування підприємствами, вибору майбутньої стратегії їх розвитку на основі державних програм фінансової підтримки, запровадження інноваційних форм фінансування (сек'юритизації) або залучення іноземних інвестицій.

Практична значимість. Полягає в можливості спрогнозувати прибутковість активів підприємств добувної галузі залежно від можливих змін їх фінансового стану та ділової активності через приплив іноземних інвестицій, 3 урахуванням масштабів і виду економічної діяльності, а також дозволить максимально ефективно використати наявний фінансовий потенціал компанії та обгрунтувати пріоритети державної підтримки.

Ключові слова: добувна промисловість, модель з випадковими ефектами, ділова активність, платоспроможність, рентабельність активів

\section{Влияние платежеспособности и деловой активности на прибыльность предприятий добывающей отрасли Украины}

\section{Н. Г. Выговская, А. Ю. Полчанов, Т. П. Остапчук, В. В. Довгалюк}

Государственный университет «Житомирская политехника», г. Житомир, Украина, e-mail: polchanov@gmail.com

Цель. Выявление взаимосвязи прибыльности предприятий добывающей отрасли с их платежеспособностью и деловой активностью для принятия оптимальных управленческих решений на основе формирования формализованной прогнозной модели, с учетом масштабов и вида экономической деятельности.

Методика. Эмпирическая база исследования была сформирована на основе ключевых показателей финансовой отчетности 75 предприятий добывающей промыш- ленности Украины в 2014-2018 гг. с помощью системы Youcontrol. Для достижения поставленной цели с помощью инструментария корреляционно-регрессионного анализа была построена модель линейной регрессии, описывающая зависимость рентабельности активов от коэффициента автономии (доли собственного капитала в общем объеме источников финансирования), оборачиваемости активов (соотношение выручки к среднегодовым активам), вида экономической деятельности (исходя из основного вида деятельности, в соответствии с Классификатором видов экономической деятельности) и масштабов бизнеса (исходя из годового объема выручки).

Результаты. Предложенная формализованная прогнозная модель позволяет выявить и оценить взаимосвязь между прибыльностью предприятий добывающей отрасли и их платежеспособностью и деловой активностью, с учетом влияния фактора эффекта масштаба и особенностей осуществления экономической деятельности. Использование предложенной модели позволяет сделать следующие выводы по планированию направлений привлечения внутренних или внешних источников финансирования предприятиями:

- во-первых, ориентация на внутренние источники финансирования деятельности предприятий будет иметь больший эффект по сравнению с использованием кредитных ресурсов. Учитывая перегруженность предприятий добывающей отрасли долгами, при разработке финансовой стратегии приоритетным направлением должна стать реструктуризация обязательств, конвертация долга в собственность, секьюритизация;

- во-вторых, учет влияния фактора эффекта масштаба в добывающей промышленности определяет приоритетом государственной политики поддержку малого бизнеса и создание условий для повышения концентрации капитала;

в-третьих, учитывая градообразующий характер предприятий этой отрасли, обоснованным является сохранение существующих и запуск новых программ финансовой поддержки предприятий, учитывая социальные последствия возможного банкротства таких предприятий.

Формализация предложенных направлений позволяет предприятиям добывающей отрасли осуществить выбор будущей стратегии их финансового развития.

Научная новизна. Заключается в формировании формализованной прогнозной модели, позволяет выявить и оценить взаимосвязь между доходностью предприятий добывающей отрасли и их платежеспособностью и деловой активностью, с учетом влияния фактора масштаба и особенностей осуществления экономической деятельности. Использование предложенной модели будет способствовать принятию эффективных управленческих решений по планированию направлений привлечения внутренних или внешних источников финансирования предприятиями, выбора будущей стратегии их развития на основе государственных программ финансовой поддержки, внедрения инновационных форм финансирования (секьюритизации) или привлечения иностранных инвестиций.

Практическая значимость. Заключается в возможности спрогнозировать прибыльность активов предприятий добывающей отрасли в зависимости от возможных изменений их финансового состояния и деловой активности из-за притока иностранных инвестиций, с учетом масштабов и вида экономической деятельности, а также позволит максимально эффективно использовать имеющийся финансовый потенциал компании и обосновать приоритеты государственной поддержки.

Ключевые слова: добывающая промышленность, модель со случайными эффектами, деловая активность, платежеспособность, рентабельность активов

Recommended for publication by L.V.Chyzhevska, Doctor of Economic Sciences. The manuscript was submitted 24.12.19. 